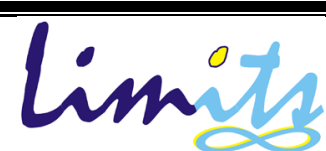

Limits: Journal of Mathematics and Its Applications

E-ISSN: 2579-8936

P-ISSN: 1829-605X

Vol. 18, No. 2, Nopember 2021, 129-141

DOI: http://dx.doi.org/10.12962/limits.v18i2.6854

\title{
Pemodelan Matematika Pada Kasus Kecanduan Game Online Menggunakan Metode Runge-Kutta Orde 14
}

\author{
Arif Fatahillah ${ }^{1}$, Maulida Istiqomah ${ }^{2}$, Dafik $^{3}$ \\ 1,2,3Program Studi (S1) Pendidikan Matematika, FKIP Universitas Jember (UNEJ) \\ Jalan Kalimantan 37 Kampus Tegalboto Jember 68121 \\ e-mail: fatahillah767@gmail.com
}

Diajukan: 29 April 2020, Diperbaiki: 22 April 2021, Diterima: 6 September 2021

\begin{abstract}
Abstrak
Banyak permasalahan di kehidupan nyata dapat dibentuk kedalam model matematika sehingga dapat dianalisis secara matematik. Salah satunya adalah kasus kecanduan game online yang sedang marak saat ini. Model matematika pada kasus kecanduan game online telah dikembangkan dan dikemas dalam model SEIRS yang berbentuk sistem persamaan diferensial biasa non linier orde satu. Model tersebut sangat kompleks sehingga memerlukan metode numerik untuk menyelesaikannya. Salah satu metode numerik yang efektif adalah metode Runge-Kutta, lebih tepatnya digunakan metode Runge-Kutta orde 14. Penelitian ini akan merumuskan formulasi metode Runge-Kutta orde empat belas dan membuat format pemrograman MATLAB kemudian menganalisis efektivitas metode tersebut dalam menyelesaikan model matematika SEIRS pada kasus kecanduan game online. Efektivitas suatu metode bergantung pada error yang dihasilkan dari eksekusi MATLAB ketika hasilnya semakin kecil (mendekati nol). Metode pengumpulan data yang digunakan adalah metode dokumentasi dan kuesioner. Hasil penelitian ini menunjukkan bahwa metode Runge-Kutta orde empat belas efektif dalam menyelesaikan model SEIRS pada kasus kecanduan game online.
\end{abstract}

Kata Kunci: Kecanduan game online, model SEIRS, metode Runge-Kutta orde 14.

\begin{abstract}
Many problems in real life can be formed into mathematical models so they can be analyzed mathematically. One of them is the case of online game addiction that is rife today. Mathematical models in the case of online game addiction have been developed into the SEIRS model in the form of a first-order non-linear differential equation system. The model is so complex that it requires numerical methods to solve it. One of the effective numerical methods is the Runge-Kutta method, more precisely the 14th order Runge-Kutta method. This research will formulate the 14th order Runge-Kutta method and create a MATLAB programming format then analyze the effectiveness of the method in completing the SEIRS mathematical model on the case of addiction to online games. The effectiveness of a method depends on the error resulting from MATLAB execution when the result is getting smaller (near zero). Data collection methods used are documentation and questionnaire methods. The results of this study indicate that the 14th order Runge-Kutta method is effective in completing the SEIRS model in cases of online game addiction.
\end{abstract}

Keywords: Online game addiction, SEIRS model, 14th order Runge-Kutta method.

\section{Pendahuluan}

Pemodelan matematika merupakan proses untuk merepresentasikan sistem atau masalah di dunia nyata kedalam pernyataan matematika. Terjemahan ide atau gagasan matematika dari suatu masalah nyata yang dihasilkan tersebut merupakan model matematika. Model matematika dalam 
menyelesaikan masalah nyata sangat beragam, pada tahun 1927 Kermack dan McKendrick [1] menciptakan model SIR yang memiliki peran penting dalam perkembangan matematika epidemi. Model SIR tersebut membagi individu kedalam 3 kelas yaitu susceptible (S), infected (I), dan recovered (R). Kini model SIR berkembang hingga memunculkan model-model lain disesuaikan dengan kasus atau permasalahan di dunia nyata. Dengan mempertimbangkan perbedaan risiko penyakit, struktur usia, pengaruh musiman, pengaruh spasional, dan beberapa model dengan penundaan waktu telah dikenalkan. Model tersebut diantaranya model SEI, SEIS, SIRS, SEIR, SEIRS, SEIQR dan banyak lainnya [2]

Penelitian ini mengembangkan model SEIR milik Danling Zhao [3] yang membahas penyebaran informasi pada jejaring sosial media online. Sama seperti model SIR, model SEIR juga membagi individu menjadi kelas-kelas. Pengguna dikelompokan menjadi 4 kelas dimana ada individu baru yaitu exposed (E) atau individu terpapar dan individu Recovered (R) mengalami kesembuhan permanen. Permasalahan yang diangkat dalam penelitian ini adalah kasus kecanduan game online yang mana individu recovered $(\mathrm{R})$ dapat kembali rentan dalam jangka waktu tertentu atau dimodelkan kedalam model SEIRS. Selain model SEIRS juga terdapat beberapa model matematika yang mengasusmsikan kesembuhan tidak permanen sehingga terjadi suatu siklus salah satunya yaitu model VEISV pada serangan virus jaringan [4]. Penelitian yang mengembangkan model SEIRS telah dilakukan oleh [5][6][7][8] untuk memperoleh solusi numerik dari penyebaran virus komputer, penyebaran penyakit menular sampai perilaku merokok seseorang.

Kecanduan game online ditandai dengan sejauh mana seseorang bermain game secara berlebihan yang dapat berpengaruh negatif bagi pemain game tersebut. Menurut WHO (World Health Organization), seseorang dikatakan kecanduan game online apabila memenuhi kriteria sebagai berikut:

1. Ada ganguan kontrol untuk melakukan permainan tersebut (tidak dapat mengendalikan diri);

2. Lebih memprioritaskan memainkan permainan tersebut dibandingkan dengan aktivitas yang seharusnya lebih diutamakan;

3. Intensitasnya semakin meningkat dan berkelanjutan meskipun ada konsekuensi atau dampak negatif yang dirasakan;

4. Perilaku berpola tersebut menyebabkan gangguan yang bermakna pada fungsi pribadi, keluarga, sosial, pendidikan dan area penting lainnya;

5. Pola tersebut sudah berlangsung selama 12 bulan.

Model SEIRS yang terbentuk berupa sistem persamaan diferensial biasa (PDB) non linier orde satu yang tidak dapat diselesaikan menggunakan metode analitik, sehingga harus diselesaikan menggunakan metode numerik. Sistem persamaan diferensial biasa adalah gabungan dua atau 
lebih persamaan diferensial yang hanya teppanyaki satu variabel bebas. Salah satu metode numerik yang efektif adalah metode Runge-Kutta yang memiliki ketelitian lebih tinggi daripada metode euler dan metode heun. Kelebihan metode ini adalah teknik yang lebih akurat karena memiliki pemenggalan yang kecil dalam pengintegrasian error. Error adalah selisih dari solusi eksak (solusi sejati) dengan solusi numerik. Metode Runge-Kutta dapat ditingkatkan menjadi orde yang lebih tinggi untuk memperoleh tingkat efektivitas lebih tinggi. Banyak penelitian sebelumnya yang mengembangkan metode Runge-Kutta, beberapa diantaranya adalah metode Runge-Kutta orde empat untuk memperoleh solusi numerik penyakit diabetes millitus[7], metode Runge-Kutta orde delapan untuk menyelesaikan model matematika penyebaran penyakit malaria [9], dan metode Runge-Kutta orde sembilan untuk menyelesaikan model infeksi mycobacterium tuberculosis [10].

Metode Runge-Kutta mempunyai tiga sifat khas yaitu:

1. Metode Runge-Kutta adalah metode satu langkah: gunakan informasi yang tersedia pada titik sebelimnya, $x_{m}, y_{m}$, untuk memperoleh $y_{m+1}$

2. Metode Runge-Kutta sesuai dengan deret Taylor sampai dengan suku $h^{p}$, dimana $p$ berbeda untuk metode berbeda dan disebut order metode tersebut,

3. Metode Runge-Kutta tidak memerlukan evaluasi setiap turunan $f(x, y)$, tetapi hanya fungsi $f$ itu sendiri.

Secara umum metode Runge-Kutta dapat dituliskan sebagai berikut:

$$
y_{n+1}=y_{n}+h \sum_{i=1}^{m} b_{i} k_{i}
$$

dimana,

$$
k_{i}=f\left(x_{n}+c_{i} h, y_{n}+\sum_{j}^{i-1} a_{i j} k_{j}\right), i=1,2, \ldots, m
$$

dengan asumsi:

$$
c_{i}=\sum_{j=i}^{m} a_{i j}, \text { dan } \sum_{i=1}^{m} b_{i}=1
$$

Nilai $a, b$, dan $c$ dapat ditulis dalam butcer array berikut: 


$$
\begin{array}{c|ccccc}
0 & & & & & \\
c_{2} & a_{21} & & & & \\
c_{3} & a_{31} & a_{32} & & & \\
\vdots & \vdots & \vdots & \ddots & & \\
c_{m} & a_{m 1} & a_{m 2} & \cdots & a_{m m-1} & \\
\hline & b_{1} & b_{2} & \cdots & b_{m-1} & b_{m}
\end{array}
$$

Penelitian ini bertujuan membentuk dan mengembangkan model matematika pada kasus kecanduan game online. Model matematika akan diselesaikan menggunakan metode Runge-Kutta orde 14. Selain itu untuk menambah pengetahuan peneliti dalam bidang pemodelan matematika dan memberikan kontribusi terhadap berkembangnya pengetahuan baru dalam bidang pemodelan matematika menggunakan metode Runge-Kutta orde 14.

\section{Metode Penelitian}

Metode penelitian adalah cara untuk memperoleh data yang akan dianalisis untuk sampai pada kesimpulan yang sesuai dengan tujuan penelitian. Penelitian ini menggunakan metode dokumentasi dan eksperimen. Metode dokumentasi digunakan untuk membuat dan mengembangkan model SEIRS pada kasus kecanduan game online. Sedangkan metode eksperimen adalah metode penelitian untuk mencari jawaban atau pemecahan dari suatu kasus ataupun obyek penelitian. Pengumpulan data dengan metode eksperimen menggunakan kuesioner yang diberikan kepada siswa SMKN 1 Jember dengan usia 15-18 tahun digunakan untuk mendapatkan nilai awal dan parameter.

Pada penelitian ini, peneliti memodelkan kasus kecanduan game online kedalam model SEIRS menggunakan metode Runge-Kutta orde 14 sehingga diperoleh efektivitasnya berdasarkan data yang diperoleh. Langkah pertama adalah membentuk dan mengembangkan model SEIRS kemudian menentukan nilai awal dan parameter dari hasil kuesioner. Langkah selanjutnya adalah membentuk formulasi metode Runge-Kutta orde 14 beserta programnya pada MATLAB dilanjutkan dengan memasukkan nilai awal dan parameter untuk mengetahui tingkat efektivitas dari hasil grafik dan error yang dihasilkan. Terakhir membuat kesimpulan berdasarkan hasil analisis.

\section{Hasil dan Pembahasan}

Model SEIRS yang dibentuk disesuaikan dengan kasus kecanduan game online dengan asumsi bahwa penelitian yang dilakukan tidak menggunakan ketentuan dari bidang kedokteran 
maupun psikologi. Model tipe SEIRS pada kasus kecanduan game online didefinisikan sebagai berikut:

- S (Susceptible) adalah individu rentan, merupakan individu yang belum mengenal game online atau sudah mengenal namun tidak bermain game online. Individu ini rentan untuk kecanduan game online.

- E (Exposed) adalah individu terpapar, merupakan individu yang bermain game online namun dengan intensitas jarang. Individu terpapar (E) dapat sembuh tanpa menjadi individu terinfeksi.

- I (Infected) adalah individu yang kecanduan game online. Kriteria sebagai berikut:

1. bermain game minimal 30 jam dalam seminggu (minimal 4 sampai 5 jam dalam sehari);

2. berlangsung selama minimal 1 tahun;

3. tidak dapat berhenti bermain game online;

4. tidak melakukan sesuatu yang seharusnya dikerjakan karena bermain game online;

5. lebih mementingkan bermain game online daripada bersosialisasi dengan lingkungan sekitar atau orang lain;

6. menyadari dampak negatif dari bermain game online namun tetap bermain game online secara terus menerus.

- $\mathrm{R}$ (Recovered) adalah individu sembuh, merupakan individu terpapar atau individu terinfeksi yang sudah berhenti bermain game online karena alasan tertentu. Individu ini dapat rentan kembali bermain game online karena penyebaran game online yang semakin pesat di era modern saat ini.

Berdasarkan definisi tersebut, kasus kecanduan game online dimodelkan sebagai berikut:

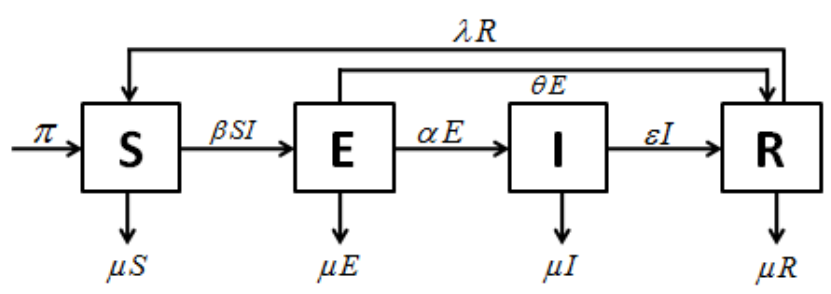

$$
\begin{aligned}
& \frac{d S}{d t}=\pi-\mu S-\beta S I+\lambda R \\
& \frac{d E}{d t}=\beta S I-\alpha E-\mu E-\theta E \\
& \frac{d I}{d t}=\alpha E-\varepsilon I-\mu I \\
& \frac{d R}{d t}=\varepsilon I-\mu R+\theta E-\lambda R
\end{aligned}
$$

Nilai awal dan parameter diperoleh dari hasil penelitian berupa pemberian angket kepada 97 siswa SMKN 1 Jember dengan rentang usia 15-18 tahun. Pemberian angket dilakukan dua kali 
dengan rentang 30 hari, untuk mengetahui perubahan yang terjadi pada individu. Hasil angket tersebut yang kemudian dijadikan sebagai perbandingan kejadian sebenarnya dan solusi numerik. Berdasarkan angket tersebut, siswa dibagi menjadi 4 golongan yaitu rentan(S), terpapar(E), terinfeksi(I), dan sembuh namun rentan(R). Berdasarkan syarat model SEIRS, dari hasil penelitian diperoleh nilai awal yaitu terdapat 52 individu rentan (S), 32 individu terpapar (E), 13 individu terinfeksi (I), dan 0 individu sembuh. Selanjutnya diamati selama 1 bulan perkembangan masingmasing individu untuk mengetahui jumlah individu sehat dan laju dari masing-masing parameter. Pada penelitian ini, pengelompokan individu SEIRS tidak menggunakan ketentuan dari bidang kedokteran maupun psikologi. Namun, hanya menggunakan syarat-syarat umum yang tampak dari perilaku pengguna game online. Jumlah individu diasumsikan konstan, tidak ada pengguna masuk maupun pengguna keluar. Sehingga nilai parameter $\pi$ dan $\mu$ bernilai 0 . Jumlah individu terpapar yaitu 32 individu dari total 52 individu rentan, sehingga laju $\beta$ atau laju perpindahan dari $\mathrm{S}$ ke $\mathrm{E}$ dalam waktu 30 hari yaitu:

$$
\beta=\frac{32}{52 \times 30}=\frac{32}{1560}=0.02
$$

Laju $\alpha$ atau laju infesi yaitu 13 individu dari total 32 individu selama 30 hari. Sehingga diperoleh parameter $\alpha$ yaitu:

$$
\alpha=\frac{13}{32 \times 30}=\frac{13}{960}=0.01
$$

Total individu sembuh yaitu 13 individu, yang berasal dari 6 dari 13 individu terinfeksi dan 7 dari 32 individu terpapar dalam waktu 30 hari, sehingga diperoleh:

$$
\begin{aligned}
& \varepsilon=\frac{6}{13 \times 30}=\frac{6}{390}=0.01 \\
& \theta=\frac{7}{32 \times 30}=\frac{7}{960}=0.007
\end{aligned}
$$

Terakhir pada individu sembuh, laju perpindahan menjadi individu rentan yaitu 1 , karena individu yang sembuh secara langsung menjadi individu rentan kembali. sehingga diperoleh: $\lambda=$ $\frac{1}{30}=0.03$

Sehingga, didapatkan model matematika SEIRS pada kasus kecanduan game online adalah sebagai berikut:

$$
\begin{array}{ll}
\frac{d S}{d t}=-0.02 S I+0.03 R & S(0)=52 \\
\frac{d E}{d t}=0.02 S I-0.017 E & E(0)=32 \\
\frac{d I}{d t}=0.01 E-0.01 I & I(0)=13
\end{array}
$$




$$
\frac{d R}{d t}=0.01 I+0.07 E-0.03 R \quad R(0)=0
$$

Tabel 1. Nilai awal

\begin{tabular}{clcc}
\hline Nilai awal & \multicolumn{1}{c}{ Definisi } & Nilai & Satuan \\
\hline$S(0)$ & Banyaknya individu rentan pada waktu $t=0$ & 52 & Individu \\
$E(0)$ & Banyaknya individu terpapar pada waktu $t=0$ & 32 & Individu \\
$I(0)$ & Banyaknya individu terinfeksi pada waktu $t=0$ & 13 & Individu \\
$R(0)$ & Banyaknya individu sembuh pada waktu $t=0$ & 0 & Individu \\
\hline
\end{tabular}

Tabel 2. Parameter

\begin{tabular}{clcc}
\hline Parameter & \multicolumn{1}{c}{ Definisi } & Nilai & Satuan \\
\hline$\pi$ & Tingkat pengguna masuk game online & 0 & Individu/hari \\
$\mu$ & Tingkat pengguna keluar game online & 0 & Individu/hari \\
$\beta$ & Laju perpindahan dari S ke E & 0.02 & Individu/hari \\
$\alpha$ & Laju perpindahan dari E ke I & 0.01 & Individu/hari \\
$\varepsilon$ & Laju kesembuhan & 0.01 & Individu/hari \\
$\lambda$ & Laju perpindahan dari R ke S & 0.03 & Individu/hari \\
$\theta$ & Laju perpindahan dari E ke R & 0.007 & Individu/hari \\
\hline
\end{tabular}

Selanjutnya Metode Runge Kutta yang dihasilkan mempunyai sifat dan formulasi sebagai berikut:

$$
\begin{aligned}
& \sum_{i=1}^{m} b_{i}=1 \text {, dimana } m=14 \\
& \sum_{i=2}^{m} b_{i} c_{i}^{p}=\frac{1}{p+1} \text {, dimana } p=1,2,3,4, \cdots, m-1 \\
& \sum_{i=3}^{m-1} b_{i}\left(\sum_{j=2}^{i-1} c_{j}^{q} a_{i j}\right)=\frac{1}{(q+1)(q+2)}, \operatorname{dimana} q=1,2,3,4, \cdots, m-3 \\
& y_{n+1}=y_{n}+\frac{h}{10000}\left(203 k_{1}+1399 k_{2}-777 k_{3}+3879 k_{4}-3770 k_{5}+5137 k_{6}\right. \\
& \quad-1071 k_{7}-1071 k_{8}+5137 k_{9}-3770 k_{10}+3879 k_{11}-777 k_{12} \\
& \left.+1399 k_{13}+203 k_{14}\right)
\end{aligned}
$$

Dengan,

$$
\begin{aligned}
& k_{1}=f\left(x_{n}, y_{n}\right) \\
& k_{2}=f\left(x_{n}+\frac{h}{13}, y_{n}+\frac{h}{13} k_{1}\right)
\end{aligned}
$$




$$
\begin{aligned}
& k_{3}=f\left(x_{n}+\frac{2 h}{13}, y_{n}+\frac{2 h}{13} k_{2}\right) \\
& k_{4}=f\left(x_{n}+\frac{3 h}{13}, y_{n}+\frac{3 h}{13} k_{3}\right) \\
& k_{5}=f\left(x_{n}+\frac{4 h}{13}, y_{n}+\frac{4 h}{13} k_{4}\right) \\
& k_{6}=f\left(x_{n}+\frac{5 h}{13}, y_{n}+\frac{h}{1742}\left(33 k_{1}-453 k_{3}+1566 k_{4}-476 k_{5}\right)\right) \\
& k_{7}=f\left(x_{n}+\frac{6 h}{13}, y_{n}+\frac{6 h}{13} k_{6}\right) \\
& k_{8}=f\left(x_{n}+\frac{7 h}{13}, y_{n}+\frac{7 h}{13} k_{7}\right) \\
& k_{9}=f\left(x_{n}+\frac{8 h}{13}, y_{n}+\frac{h}{702}\left(191 k_{2}-122 k_{5}+419 k_{6}+79 k_{7}-135 k_{8}\right)\right) \\
& k_{10}=f\left(x_{n}+\frac{9 h}{13}, y_{n}+\frac{9 h}{13} k_{9}\right) \\
& k_{11}=f\left(x_{n}+\frac{10 h}{13}, y_{n}+\frac{h}{1248}\left(-197 k_{4}+1574 k_{9}-417 k_{10}\right)\right) \\
& k_{12}=f\left(x_{n}+\frac{11 h}{13}, y_{n}+\frac{11 h}{13} k_{10}\right) \\
& k_{13}=f\left(x_{n}+\frac{12 h}{13}, y_{n}+\frac{h}{2444}\left(-307 k_{3}+2785 k_{11}-222 k_{12}\right)\right) \\
& k_{14}=f\left(x_{n}+\frac{13 h}{13}, y_{n}+\frac{h}{1118}\left(523 k_{6}+595 k_{13}\right)\right)
\end{aligned}
$$

Dengan membuat program MATLAB berdasarkan formulasi metode Runge-Kutta orde 14 yang terbentuk dan memasukkan model SEIRS pada kasus kecanduan game online, nilai awal dan parameter, maka diperoleh solusi numerik berupa grafik jumlah masing-masing individu dan grafik error pada metode Runge-Kutta orde 14.

Pada penelitian ini digunakan ukuran langkah $(h=0.01)$. Ukuran langkah 0.01 memiliki arti bahwa pengamatan dilakukan setiap hari dengan peningkatan seperseratus setiap waktunya. Pengambilan nilai ukuran langkah $\mathrm{h}=0.01$ sudah cukup menggambarkan akurasi karena kesalahan (error) yang terjadi cukup kecil. Dengan mengetahui solusi numerik dari suatu permasalahan, dapat ditentukan penyelesaian yang tepat. Pada penelitian milik Syafrudin side [7], hanya mencari solusi numerik dari penyakit diabetes millitus namun tidak menjelaskan efektivitas metode yang 
digunakan seperti pada penelitian [8][9]. Dapat diketahui pada setiap peningkatan orde, tingkat efektivitas juga semakin tinggi, karena nilai error semakin kecil.

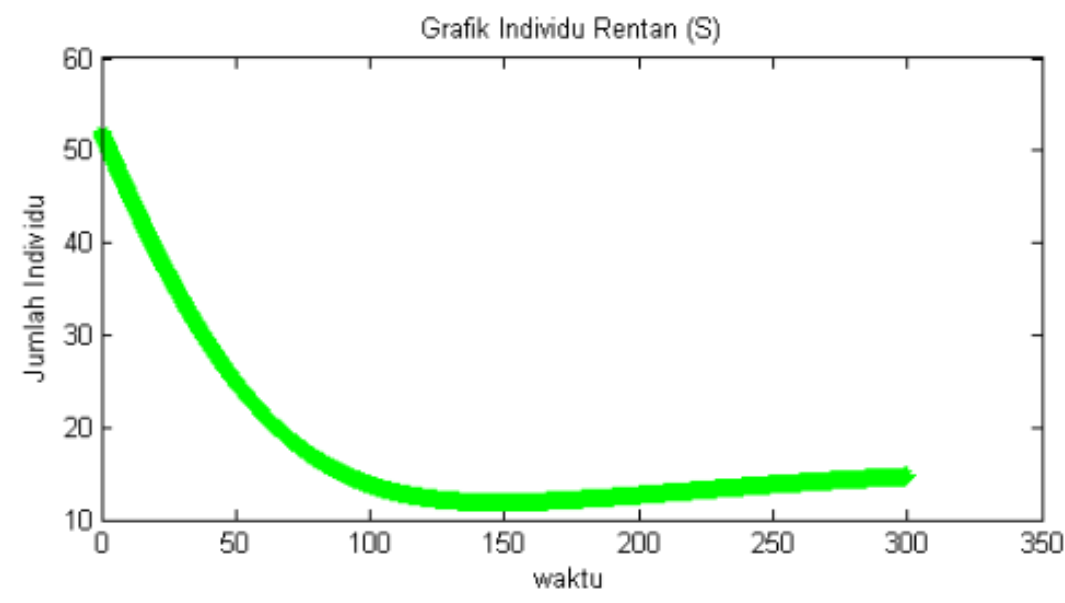

Gambar 1. Grafik eksekusi RK14 pada Individu S dengan $h=0.01$

Gambar 1 merupakan grafik hasil eksekusi metode Runge-Kutta orde 14 pada individu rentan (S). Pada grafik tersebut terlihat bahwa individu rentan mengalami penurunan pada hari pertama sampai hari ke-150 dari nilai awal 52 individu sampai mendekati nilai 0 . Hal tersebut dikarenakan individu rentan akan terus berpindah menjadi individu terpapar maupun terinfeksi dari waktu ke waktu secara perlahan. Sesuai dengan kondisi saat ini, dimana remaja akan mulai bermain game online karena pengaruh lingkungan dan perkembangan game online yang sangat pesat saat ini dengan modifikasi yang semakin mudah untuk dimainkan. Selanjutnya pada hari ke150 dan seterusnya grafik mulai naik karena adanya perpindahan individu sembuh yang kembali menjadi individu rentan.

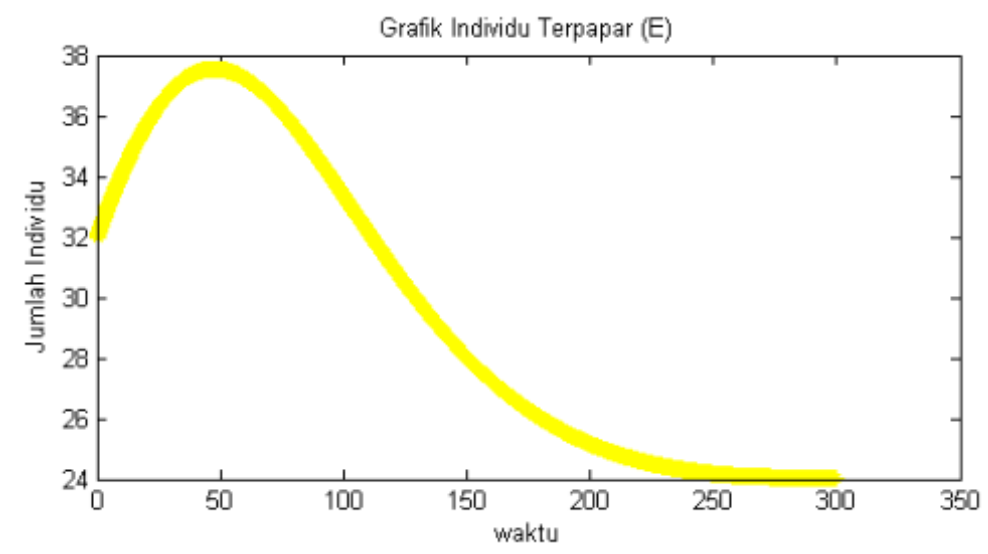

Gambar 2. Grafik eksekusi RK14 pada Individu E dengan $h=0.01$

Gambar 2 merupakan hasil eksekusi program MATLAB pada individu terpapar (E). Gambar tersebut menunjukkan bahwa pada hari pertama sampai ke-50 grafik mengalami kenaikan yang disebabkan adanya perpindahan individu rentan menjadi terpapar lebih besar dibandingkan 
perpindahan individu terpapar menjadi individu terinfeksi. Selanjutnya pada hari ke-50 dan seterusnya grafik mengalami penurunan sampai mendekati nilai 0 karena dari waktu ke waktu individu terpapar akan berpindah menjadi individu terinfeksi maupun langsung menjadi individu sehat namun rentan. Saat ini remaja seringkali bermain game online tidak berkelanjutan, namun dalam waktu tertentu akan kembali memainkan game online sesuai dengan kebutuhan mereka.

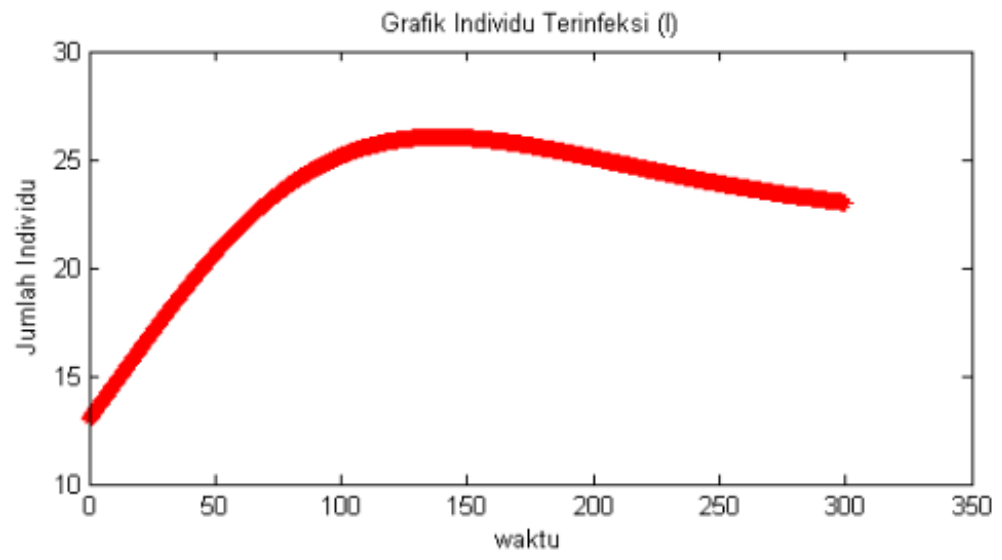

Gambar 3. Grafik eksekusi RK14 pada Individu I dengan $h=0.01$

Gambar 3 merupakan grafik eksekusi MATLAB pada individu terinfeksi (I). Gambar tersebut menunjukkan grafik mengalami kenaikan individu terinfeksi pada hari pertama sampai hari ke-150 sekitar 12 individu yang disebabkan perpindahan dari individu terpapar. Individu terinfeksi pada dasarnya merupakan individu terpapar yang terus menerus bermain game online dengan intensitas yang sering. Namun, pada hari ke-150 dan seterusnya mulai mengalami penurunan sedikit demi sedikit karena berpindah menjadi individu sehat namun rentan.

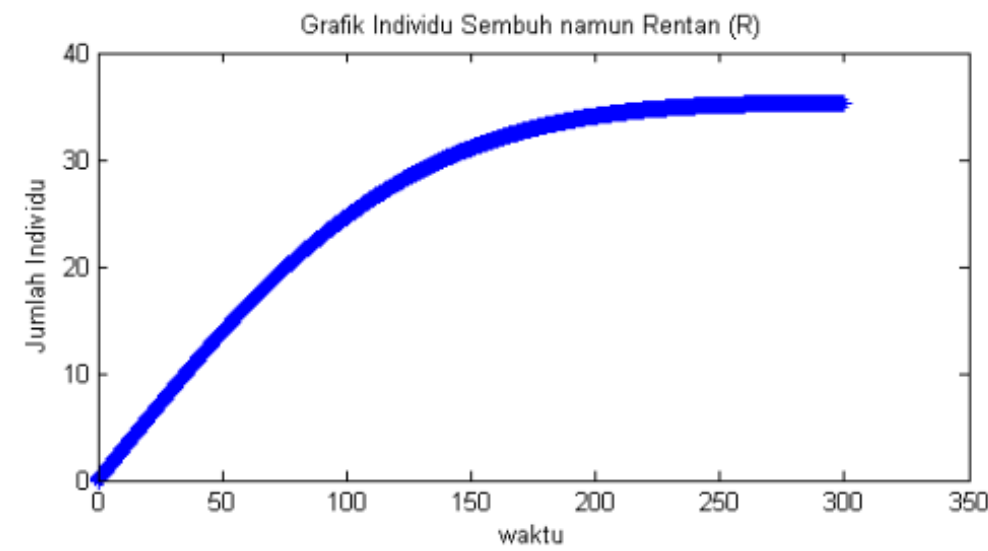

Gambar 4. Grafik eksekusi RK14 pada Individu R dengan $h=0.01$

Gambar 4 merupakan grafik hasil eksekusi program MATLAB pada individu sehat namun rentan (R). Grafik menunjukkan kenaikan dari hari pertama sampai hari ke-150 dengan jumlah sekitar 30 individu yang diperoleh dari perpindahan individu terpapar dan individu terinfeksi yang 
perlahan sembuh. Selanjutnya grafik konstan di titik 35 yang menunjukkan jumlah individu sehat namun rentan.

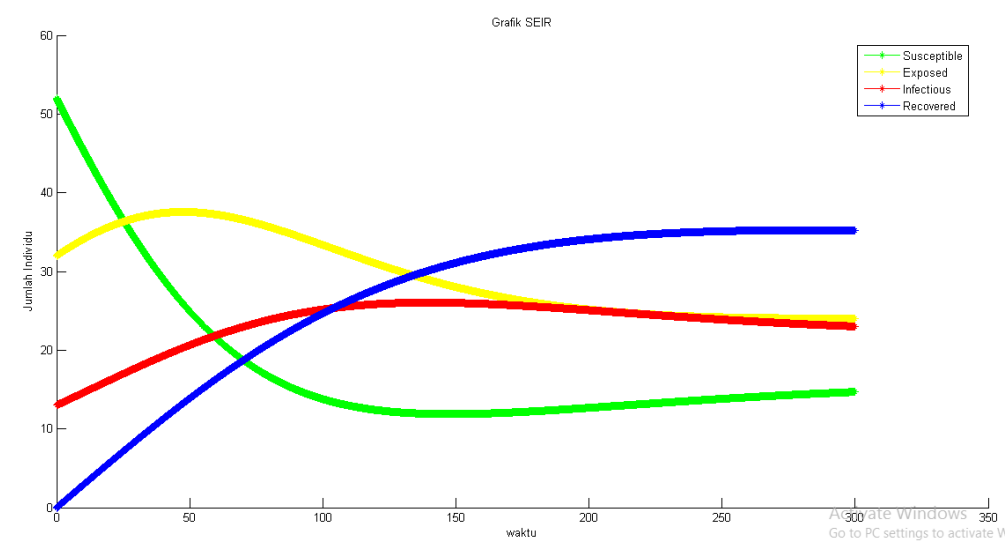

Gambar 5. Grafik eksekusi RK14 iterasi 30000 dengan $h=0.01$

Gambar 5 merupakan hasil eksekusi program MATLAB dari gabungan seluruh individu rentan, terpapar, terinfeksi dan sehat namun rentan. Grafik menujukkan total individu pada penelitian ini konstan yaitu 97 individu pada setiap iterasi yang dihasilkan.
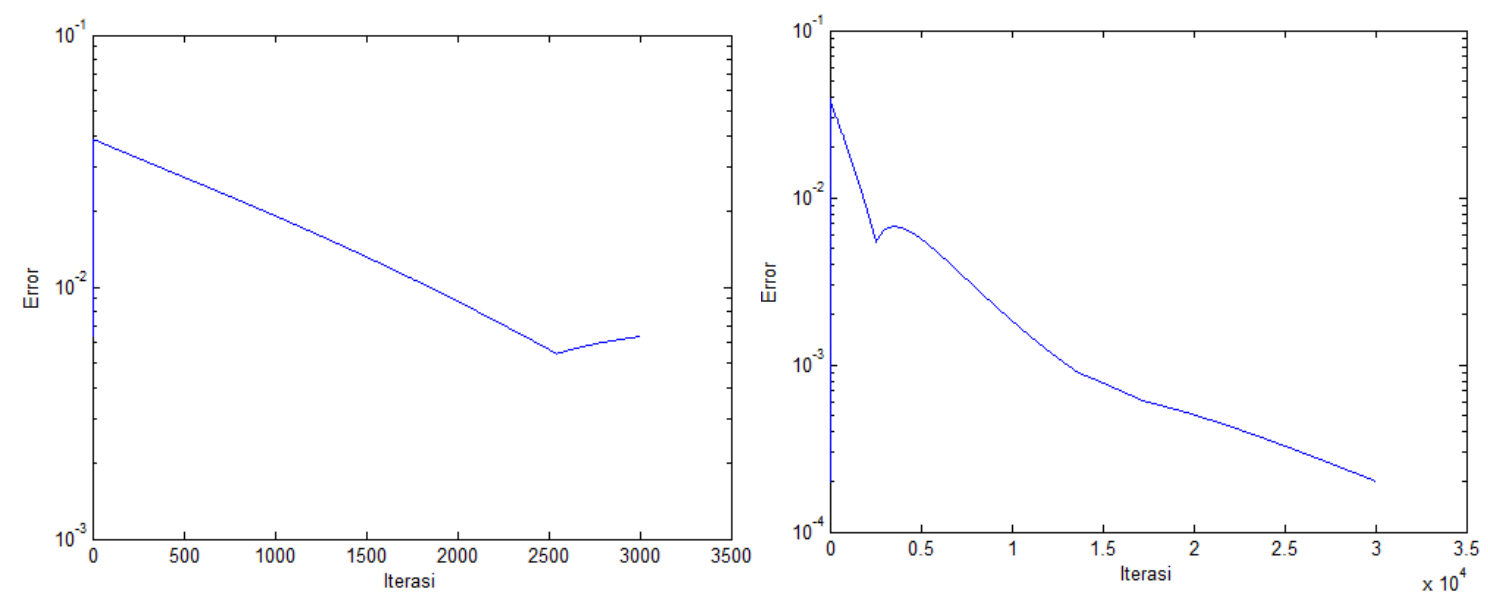

Gambar 6. Grafik Eksekusi RK14 3000 iterasi dan 30000 iterasi

Gambar 6 menunjukkan grafik nilai error dari metode Runge-Kutta orde 14. Penentuan nilai error menggunakan program MATLAB yaitu while... end. Pada iterasi 3000 yang digunakan dapat dilihat bahwa grafik terus mengalami penurunan dari iterasi kedua sampai iterasi ke-2500. Selanjutnya grafik mengalami sedikit kenaikan dari iterasi ke-2500 sampai iterasi 5000 namun masih dengan nilai error yang kecil. Pada iterasi ke-5000 grafik terus mengalami penurunan hingga mencapai nilai error 0.011. Nilai error terus menurun pada iterasi 30000 mencapai 0.0003 dan terus menurun pada iterasi berikutnya. Hal tersebut menujukkan bahwa metode Runge Kutta orde 14 konvergen dan efektif dalam menentukan solusi numerik pada kasus kecanduan game online. 
Berikut ini Data Efektivitas Metode Runge-Kutta Orde 14 dengan beberapa nilai error yang dipilih.

Tabel 3. Data Efektivitas Metode Runge Kutta Orde 14

\begin{tabular}{ccc}
\hline Iterasi ke- & Error Relatif & Waktu (detik) \\
\hline 50 & 0.07040 & 4.1880 \\
100 & 0.06827 & 6.6780 \\
300 & 0.06052 & 8.6590 \\
500 & 0.05367 & 8.8700 \\
1000 & 0.03890 & 11.0240 \\
3000 & 0.01180 & 22.8490 \\
5000 & 0.01027 & 28.4300 \\
10000 & 0.003114 & 58.1170 \\
30000 & 0.0003248 & 316.5290 \\
50000 & 0.00004027 & 823.9020 \\
\hline
\end{tabular}

\section{Simpulan}

Berdasarkan penelitian yang dilakukan, simpulan yang dihasilkan yaitu:

- kasus kecanduan game online dapat dibentuk kedalam model SEIRS dengan asumsi bahwa individu akan mengalami siklus dimana tidak terjadi kesembuhan permanen sehingga mengakibatkan individu yang mengalami kecanduan game online dapat kemabali rentan, terpapar, dan seterusnya.

- hasil eksekusi programming MATLAB menunjukkan metode Runge-Kutta orde 14 efektif dalam menyelesaikan model SEIRS pada kasus kecanduan game online. Grafik yang dihasilkan dari program MATLAB menggunakan metode Runge-Kutta tersebut mempunyai nilai error yang kecil dan semakin mendekati nol dengan adanya penambahan iterasi.

\section{Daftar Pustaka}

[1] W.O. Kermack and A.G. McKendrick, "A Contribution to the Mathematical Theory of Epidemics.," part 1, Proc. R. Soc. Lond. Ser. A Math. Phys. Eng. Sci. vol. 115, pp. 700 $721,1927$.

[2] G. Lu and Z. Lu, "Geometric approach to global asymptotic stability for the SEIRS models in epidemiology," Nonlinear Anal. Real World Appl., vol. 36, no. 20115134110001 , pp. 20-43, 2017.

[3] D. Zhao, J. Sun, Y. Tan, J. Wu, and Y. Dou, "The SEIR model is extended to illustrate the propagation dynamics of," Physica A, 2018. 
[4] O. A. Toutonji, S. Yoo, and M. Park, "Stability analysis of VEISV propagation modeling for network worm attack," Appl. Math. Model., vol. 36, no. 6, pp. 2751-2761, 2012.

[5] G. Lu and Z. Lu, "Global asymptotic stability for the SEIRS models with varying total population size," Math. Biosci., 2017.

[6] J. D. H. Guillén, A. M. Rey, and L. H. Encinas, "Study of the stability of a SEIRS model for computer worm propagation," Physica A, 2017.

[7] S. Side, G. P. Astari, and M. I. Pratama, "Numerical Solution of Diabetes Mellitus Model without Genetic Factors with Treatment using Runge Kutta Method,” J. Phys. Conf. Ser., 2019.

[8] G. Rahman, R. Agarwal, and Q. Din, "Mathematical analysis of giving up smoking model via harmonic mean type incidence rate," Appl. Math. Comput., vol. 354, pp. 128-148, 2019.

[9] R. Ardhilia, Dafik, and S. Setiawani, "Effectiveness of eighth order runge-kutta method to solve the mathematical model of malaria disease transmission," vol. 4, no. 2, pp. 59-74, 2013.

[10] D. Anggraeni, Dafik, and S. Setiawani, "The effectiveness of runge-kutta method of order nine to solve the immunity model for infection of mycobacterium tuberculosis," vol. 4, no. 2, pp. 75-88, 2013. 